\title{
Smooth Muscle Tissue
}

National Cancer Institute

\section{Source}

National Cancer Institute. Smooth Muscle Tissue. NCI Thesaurus. Code C12437.

Involuntary muscle tissue of the internal organs. It is composed of elong ated muscle

cells or fibers that are not arranged in a striated pattern and form layers of muscle

tissue. The smooth muscle cells contain a contractile apparatus composed of thin and thick filaments and a cytoskeleton composed of intermediate filaments. 